\title{
Germination Response of Three Globemallow Species to Chemical Treatment
}

\author{
TIMOTHY E. ROTH, J.L. HOLECHEK, AND MOHAMMED Y. HUSSAIN
}

\begin{abstract}
Scarlet (Sphaeralcea coccinea), orange (Sphaeralcea muaroana), and gooseberry globemallow (Sphaeralcea grossulariaefolia) seed were soaked in $18 \mathrm{~m}$ sulfuric acid; $1 \mathrm{~m}, 1,4$-dioxane; and sulfuric acid plus dioxane to increase germination. A 3 to 4 -hour soak in dioxane significantly $(P<.05)$ improved germination of all species over the control, and was the best treatment when data were pooled across species. Scarlet globemallow had the highest germination when subjected to 10-minute soak in sulfuric acid. Dioxane is a highly flammable, potentially cancer inducing chemical not readily available to most personnel interested in seeding globemallow. In contrast, sulfuric acid is a readily available chemical that poses a relatively minimal hazard to human health if handled correctly. A 10-minute soak in sulfuric acid appears to be a very practical treatment for improving the germination of scarlet and gooseberry globemallow. However, orange globemallow germination $(P>.05)$ was not improved by sulfuric acid treatment.
\end{abstract}

Key Words: forbs, seeding, plant establishment

Globemallow (Sphaeralcea sp.) is a common herbaceous plant occurring throughout most of New Mexico and the desert Southwest (Kearney and Peebles 1951, Martin and Hutchins 1980). Although little information is available concerning globemallow germination, plants of this genus are considered highly palatable and nutritious both for livestock and big game (Kautz and Van Dyne 1978, Stephenson et al. 1985).

Establishment of herbaceous species on rangelands in New Mexico is highly correlated with precipitation (Bridges 1942). Growth and establishment of forbs is affected by self-induced dormancy (Raven et al. 1976). Even when environmental conditions are favorable, some seeds will fail to germinate. Seed dormancy is a state of seed development that insures species survival over a wide range of adverse environmental conditions (McDonough 1977). Seed dormancy in globemallow depends on the seed physical properties and the presence of a nonwater soluble substance contained in the seed coat (Page et al. 1966).

Altering seed coat porosity may increase globemallow establishment. The objective of this study was to determine the germinative response of 3 species of globemallow to chemical and mechanical treatments designed to enhance germination by altering seed coat properties.

\footnotetext{
Authors are graduate research assistant and associate professor, Department of Animal and Range Sciences, and associate professor, Department of Experimental Statistics, New Mexico State University, Las Cruces 88003.

This is Journal Article 1198 of the Agr. Exp. Sta., New Mexico State University, Las Cruces 88003. Funding for the study was provided by the New Mexico Agricultural Experiment Station.

Manuscript accepted 8 September 1986.
}

\section{Materials and Methods}

Seeds from 3 different globemallow species were collected in different regions of the western United States. The 3 species were scarlet globemallow (Sphaeralcea coccinea), , orange globemallow (S. munroana) and 2 accessions of gooseberry globemallow ( $S$. grossulariaefolia). Seed from orange globemallow was collected in west-central Idaho; scarlet globemallow seed was from southcentral Colorado; gooseberry globemallow seed ( 2 accessions) was collected in northern Utah.

Three chemical treatments were used to stimulate germination. These involved immersion of seed in sulfuric acid, dioxane, and sulfuric acid plux dioxane.

Sulfuric acid (18 molar) was used to chemically scarify the seed coat. Each species of seed was allowed to soak, without stirring, in $50-\mathrm{ml}$ beakers each containing $10 \mathrm{ml}$ of the sulfuric acid warmed at room temperature. At the end of each time frame, seeds were removed from the acid, rinsed in tap water, placed on paper towels and allowed to dry. Seeds were divided into two 50-seed replications per species after drying.

One molar 1,4-dioxane was used to determine if a nonwater soluble inhibitor was present in all varieties of globemallow. This treatment was selected because research by Page et al. (1966) indicated that removal of nonwater soluble material might enhance globemallow germination. Readers are warned dioxane is a cancer inducing chemical of high flammability so it must be handled with great care. Seed of each was placed in 50-ml beakers to which $10 \mathrm{ml}$ dioxane was added. Times of immersion were 2, 3, 4,5 , and 6 hours. At the end of each time frame, seeds were removed from the dioxane, rinsed in tap water, placed on paper towels and allowed to dry. Seeds were divided into two 50-seed replicates per species after drying.

To determine if the carpel had any effect upon germination, the seeds of scarlet and orange globemallow were used (seed of gooseberry globemallow does not have a persistent carpel). The carpels for both species were removed by soaking for 2 to 3 minutes in 10 $\mathrm{ml}$ sulfuric acid in 50-ml beakers. Seeds were rinsed in tap water to remove the acid and then placed in $50-\mathrm{ml}$ beakers containing $10 \mathrm{ml}$ dioxane. Times of immersion in dioxane were the same as the previously described dioxane experiment. At the end of each time frame, seeds were rinsed in tap water to remove the chemical and were placed on paper towels and allowed to dry. Seeds were divided into two 50-seed replicates per species after drying.

The influence of mechanical scarification was also evaluated. Seeds from all species were placed in a rotating metal drum lined with sandpaper for periods of $10,15,20$, and 25 seconds. Because scarlet and orange globemallow seeds were covered with carpels, these were removed by hand before treatment. This was done to 


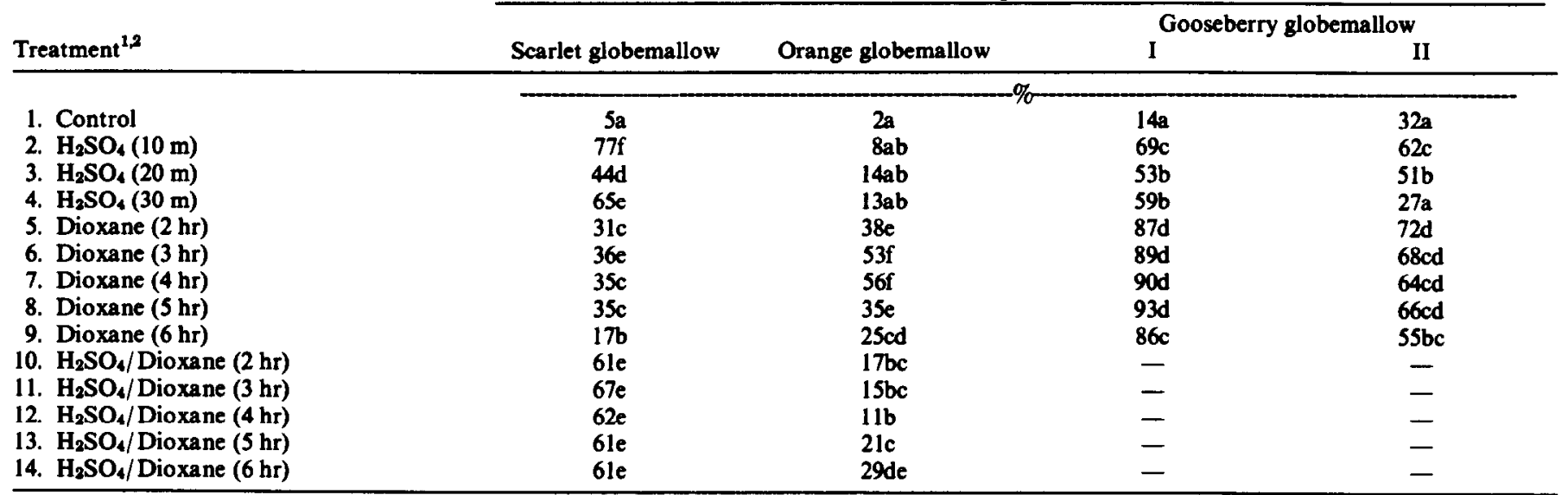

'Treatments within columns with different letters are significantly different $(R<05)$ using the LSD test.

${ }_{2}$ Numbers in parenthesis refer to length of time soaked in the chemical.

study actual seedcoat scarification. Seed was divided into two 50-seed replicates per species after scarification.

After application of the 4 treatments and division into replicates, seeds were placed on water-saturated filter paper within plastic petri dishes. The petri dishes were placed randomly inside a walk-in germinator, which was maintained at total darkness. Temperature was maintained at a constant $25^{\circ} \mathrm{C}$.

Dishes were checked daily in order to determine the initiation and duration of germination. Seeds were considered germinated when the radicle had elongated to a length of $1 \mathrm{~cm}$. Observations were continued for 21 days.

Every chemical/time combination was considered a treatment (Table 1). The number of nonviable seeds was subtracted from the total to calculate percent germination. Therefore, germination is expressed as the percent of viable seeds germinating. Germination data were analyzed using a two-way (species $X$ treatment) randomized least squares analysis of variance. Differences between means were tested using the Least Significant Difference method. Mechanical scarification data were analyzed separately from data involving chemical treatments.

\section{Results and Discussion}

\section{Control Germination}

Germination for the control treatment showed considerable variation among globemallow species (5 to 32\%) (Table 1). Accession II of gooseberry globemallow had over twice the percent germination of Accession I. The variation between the 2 collections is probably due in part to year of seed collection. Research on other species shows seeds collected on the same site in different years can vary considerably in germination (Young and Evans 1977). Harvest date and storage methods can also affect relative germination between plant species and varieties (Waller et al. 1983).

\section{Scarification with $\mathrm{H}_{2} \mathrm{SO}_{4}$}

The 10-minute soak in sulfuric acid gave the significantly highest $(P<.05)$ germination for scarlet globemallow and greatly increased $(P<.05)$ gooseberry globemallow germination over the control (Table 1). However, sulfuric acid had no significant effect $(P>.05)$ on orange globemallow germination. Page et al. (1966) reported gooseberry globemallow had germinations of 30 to $40 \%$ when treated with $\mathrm{H}_{2} \mathrm{HO}_{4}$. Both our and their results show no advantage (in our study germination decreased) to soaking periods over 10 minutes.

\section{Organic Solvent Soaking}

Dioxane increased $(P<.05)$ the germination of all globemallow species over the control (Table 1). Soaking in dioxane compared to other treatments gave the highest germinations for both accessions of gooseberry globemallow and for orange globemallow. Page et al. (1966) reported gooseberry globemallow seed treated with dioxane had germinations of $37,52,48$, and $67 \%$ for $1,2,3$, and $4 \mathrm{hr}$ soaks in dioxane, respectively. Our results are consistent with theirs in showing soaking in dioxane can be a useful method of improving globemallow germination. The influence of dioxane soaking period on germination was inconsistent among species. However, the 3 hour soak gave a relatively high percent germination for all 3 species. It would appear to be the best choice for personnel interested in improving germination of other native globemallow species by treatment with dioxane.

\section{Comblnation Organic Solvent and Acid Scarification}

Combination organic solvent plus acid scarification showed no advantage over single use of either sulfuric acid or dioxane treatments for any species (Table 1). The combination treatment did improve the germination of scarlet globemallow compared to dioxane alone. However, the 10 minute soak in sulfuric acid gave the highest germination for scarlet globemallow.

\section{Mechanical Treatment}

Mechanical scarification increased the germination of all globemallow species in our study. However, for all species and time frames, all embryos were damaged and did not live beyond 7 days. Page et al. (1966) found gooseberry globemallow germination decreased from $47 \%$ to $8 \%$ as mechanical scarification time increased from 5 seconds to 25 seconds. Both our and their results showed great care must be exercised to prevent seed damage when mechanical scarification is used.

\section{Conclusions}

Results from our study indicate soaking in sulfuric acid or dioxane has potential to greatly increase the germination of native globemallow species. These findings have economic implications because these globemallows are palatable and nutritious to livestock, their seed is difficult to collect, and their seed is in demand and expensive (over $\$ 100 / \mathrm{kg}$ ). Although dioxane improved the germination of all 3 globemallow species in our study, it has the disadvantages of being cancer inducing, highly flammable, and not readily available to many personnel interested in seeding globemallow. Sulfuric acid was less consistent across globemallow species in increasing germination. However, a 10 -minute soak in sulfuric acid gave highest germination for scarlet globemallow and it improved gooseberry globemallow germination. It is a much more practical 
treatment due to its availability and relative low hazard to human health.

\section{Literature Cited}

Bridges, J.P. 1942. Reseeding practices for New Mexico ranges. New Mexico Agr. Sta. Bull. 291.

Kautz, J.E., and G.M. Van Dyne. 1978. Comparative analyses of diets of bison, cattle, sheep, and pronghorn antelope on shortgrass prairie in northeastern Colorado. In: D.N. Hyder (ed.). Proc. First Int. Range. Cong. Soc. Range Manage. Denver, Colo.

Kearney, T.H., and R.R. Peebles. 1951. Arizona flora. Univ. California Press, Berkeley.

Martin, W.C., and C.R. Hutchens. 1980. A flora of New Mexico. Strauss and Cramer Pub. Co., Hirschberg, West Germany.
MeDonough, W.T. 1977. Seed physiology. P. 156-184. I: R.E. Sosebee (ed.), Rangeland plant physiology. Soc. Range Manage. Denver, Colo. Page, R.J., D.L. Goodwin, and N.E. West. 1966. Germination requirements of scarlet globemallow. J. Range Manage. 19:145-146.

Raven, P.H., R.F. Evert, and H. Curtis. 1976. Biology of plants. Worth Publishers, New York.

Stephenson, T.E., J.L. Holechek, and C.B. Kuykendall. 1985. Drought effect on pronghorn and other ungulates. J. Wildl. Manage. 49:146-151.

Waller, S.S., C.M. Britton, D.K. Schmidt, J. Stubbendleck, and F.A. Sneva. 1983. Germination characteristics of two varieties of Kochia prostrata. J. Range Manage. 36:242-246.

Young, J.A., and R.A. Evans. 1977. Squirreltail seed germination. J. Range Manage. 30:33-36. 